\title{
GOVERNING REDD+: A STATE OF THE ART REVIEW
}

\author{
Submission: $20 / 12 / 2018$ \\ Accept: 03/04/2019 \\ Vanessa C. Pinsky ${ }^{1}$ \\ Isak Kruglianskas ${ }^{2}$
}

\section{ABSTRACT}

Climate change is a daunting problem that results in actions-interactions from a number of actors in complex global systems, which require multi-level governance and a myriad of international and national policies. Deforestation is the second largest source of greenhouse gas (GHG) emissions. Success in this area can have a large impact on mitigation. We focus on the governance of 'Reducing Emissions from Deforestation and Forest Degradation' (REDD+), a large scale experiment in climate finance and a promising cost-effective mitigation mechanism to motivate developing countries to implement policy approaches to reduce forest-related GHG emissions. REDD+, in the context of strengthening the global response to the threat of climate change, is considered a breakthrough mechanism in international cooperation under the United Nations Framework Convention on Climate Change (UNFCCC) regime, as it was designed to be performance-based. In this paper we analyze a state of the art review on governing REDD+ based on a systematic analysis of peer-reviewed articles in the field. Ours results present a historical perspective of REDD+, literature review, and indicate the most relevant works and scholars in the field.

Keywords: Climate change; Climate finance; Warsaw Framework; Results-based finance; Amazon Fund.

\footnotetext{
1 Professor at FIA Business School and a research fellow at the School of Economics, Management and Accounting at University of Sao Paulo. She was visiting researcher at the School of Global Policy \& Strategy at University of California San Diego. Her research focuses on REDD+, climate finance, and ecoinnovation. Vanessa's interests also include the interaction between public policies focused on the environment, corporate sustainability and innovation strategies. She is also a practitioner with over 20 years of professional experience in the areas of corporate sustainability, philanthropy, corporate affairs, marketing and communications, having worked in multinational companies in the financial and IT sectors in Brazil. E-mail: vanessa.pinsky@usp.br 2 Full professor at the School of Economics, Management and Accounting at University of Sao Paulo. Also, president at the Fundação Instituto de Administração (FIA), and leading coordinator of the Research Program on Strategic Sustainability Management (PROGESA). He was a visiting professor at Bentley School and Youngstown State University in the US. He is a consultant in corporate sustainability and innovation strategies. Member of scientific and organizational committees of national and international events. He advises several Brazilian and international organizations such as OPAS, OEA, IICA, CAPES, FAPESP, and CNPq. He author of hundreds research articles, essays and books. E-mail: ikruglia@usp.br
} 


\section{INTRODUCTION}

Since the late 1980 s policy makers and scholars have had increased interest in the governance of complex global problems related to global warming due to the risks involved and high costs of adaptation and mitigation. The 1992 United Nations Framework Convention on Climate Change (UNFCCC), adopted at the Earth Summit in Rio de Janeiro by 197 Parties, and the 1997 Kyoto Protocol, ratified by 192 Parties, are considered landmarks of the international diplomacy on climate change, which places the stabilization of GHG emissions at a 'safe level' as the ultimate objective.

International negotiations on climate change have been taking place for over 20 years. However, global GHG emissions have continued increasing (Prins \& Rayner, 2007). The consensus-oriented decision rule system of the United Nations is very complex because it involves many countries with different circumstances and a variety of complex issues. The Kyoto Protocol settled universal and legally binding commitments on mitigation and adaptation, including internationally binding emission reduction targets for developed countries. On the other hand, it imposed no limits on GHG emissions for developing countries under the principle of common but differentiated responsibilities (Falkner, Stephan, \& Vogler, 2010; Victor, 2011).

In November 2016 the Paris Agreement on climate change entered into force, and will replace the Kyoto Protocol by 2020 . It has three major aims: 1 ) keeping the increase in the global average temperature below $2{ }^{\circ} \mathrm{C}$ above pre-industrial levels and to pursue efforts to limit the temperature increase to $1.5^{\circ} \mathrm{C}$ above pre-industrial levels; 2 ) increasing the ability to adapt to the adverse impacts of climate change and foster climate resilience and low GHG emissions, and 3) making finance flows consistent with a pathway towards low GHG emissions and climate-resilient development (UNFCCC, 2015).

The Paris Agreement is a hybrid international agreement with a mix of bottom-up and top-down architecture. It combines top-down elements for oversight, guidance, and coordination. The new flexible bottom-up approach, instead of setting top-down emission reduction targets, is represented by the Nationally Determined Contributions (NDCs), in which all Parties to the Convention submitted their national targets and actions (post 2020) to be taken under the new international climate agreement. Countries' individual pledges, except for the EU, which submitted one INDC on behalf of its 28 Member States, include a range of policy actions based on countries' institutional, economic, political and technological capacities (UNFCCC, 2015).

The private sector has been responsive to climate change by establishing GHG emission reduction targets (Cruz, Gomes, Oliveira, \& Oliveira, 2017; De Farias \& Andrade, 2013; Gibaut \& Dias Filho, 2016). Companies are developing business strategies aligned with the Paris Agreement goals by committing to set science-based targets, including major multinational organizations such as Walmart and McDonald's (Danigelis, 2018, December 12).

On the forest sector, deforestation is a major driver of climate change (Lederer, 2012), and the second largest source of $\mathrm{CO} 2$ in the atmosphere after fossil fuel combustion, accounting for $12 \%$ of the global anthropogenic carbon emissions (Van der Werf et al., 2009). According to the IPCC Fifth Assessment Report (AR5) WGIII, the Agriculture, Forestry and Other Land Use (AFOLU) is a unique sector where total anthropogenic GHG emissions (CO2 eq.) are going flat and its share has declined to $24 \%$ in 2010 , mostly due to increases in emissions in the energy sector, combined with decreasing deforestation rates and increased afforestation (Smith et al., 2014). Actions to reduce deforestation and forest degradation are considered a cost-effective way to curb emissions because large-scale programs can be carried out very quickly (Stern, 2007). 
Forests have a significant potential for climate change mitigation, considering afforestation and reforestation activities, forest management, reduction of the deforestation rate, management of forestry products, use of forestry products for bioenergy production instead of using fossil fuels, and improvement of forest species aiming at increasing biomass productivity (Krug, 2008 , p. 49). These examples of productive activities in the forestry sector constitute a powerful lever for social and economic development while promoting sustainable forest management (Ab'Sáber, Goldemberg, Rodés, \& Zulauf, 1990).

There is important progress worldwide in curbing emissions from land use changes over the last decades. According to the Food and Agriculture Organization (FAO, 2016), in 1990 the world had 4,128 million ha of forest, decreasing to 3,999 million ha in 2015. Between 2010 and 2015, the global net forest loss was 3.3 million ha per year. Most of the forest loss took place in the tropics, especially in South America and Africa. Although the extent of forests continues to decline, the net forest loss rate has been cut due to the improvement of sustainable forest management activities.

REDD+ stands for "reducing emissions from deforestation and forest degradation, and the role of conservation, sustainable management of forests and enhancement of forest carbon stocks in developing countries" (UNFCCC, 2014, p. 6). It is a performance-based mechanism to mitigate forest-related carbon emissions in which developing countries receive incentives to improve forest management by attributing an economic value to the additional carbon stored in trees or not emitted (Corbera \& Schroeder, 2011).

Furthermore, REDD+ is a large scale governance experiment (Lederer, 2012), considered by some to be an experiment in transformative climate governance that leads to new perspectives by involving a diversity of actors and groups with different interests in policy implementation (Kaisa et al., 2017). Although REDD+ is not a panacea for climate change, the mechanism is considered a cost-effective approach for mitigation if compared to other alternatives (Angelsen \& McNeill, 2012; Phelps, Guerrero, Dalabajan, Young, \& Webb, 2010).

REDD+ has been negotiated under the UNFCCC regime since 2005 although the international debate on the need to develop financial mechanisms to protect tropical forests under the climate regime has been increasing since 1997, with the adoption of the Kyoto Protocol. In 2003, during COP-9, Brazilian researchers presented the concept of compensated emission reduction (Santilli et al., 2005) to develop a new financial mechanism on a global scale as part of the Convention.

UNFCCC has been providing methodological guidance for the implementation of REDD+ as part of the 2010 Cancun Agreement, the 2011 Durban Platform for Enhanced Action, the 2012 Doha Climate Gateway, and the 2013 WFR. After almost ten years, the international negotiation on REDD+ was concluded in June 2015 in Bonn. The final decisions on methodological guidance for REDD+, which culminated in the adoption of the WFR, were submitted to the negotiators of the Paris Agreement. The mechanism was included in Article 5 of the Paris Agreement:

Parties should take action to conserve and enhance, as appropriate, sinks and reservoirs of greenhouse gases as referred to in Article 4, paragraph 1(d), of the Convention, including forests. Parties are encouraged to take action to implement and support, including through results-based payments, the existing framework as set out in related guidance and decisions already agreed under the Convention for: policy approaches and positive incentives for activities relating to reducing emissions from deforestation and forest degradation, and the role of conservation, sustainable management of forests and enhancement of forest carbon. (UNFCCC, 2015, pp. 23-24, para. 2)

Within the adoption of the Paris Agreement in 2016, it is expected that by the time the Green Climate Fund (GCF) becomes fully operational, it will be a major channel to provide re- 
sults-based payments on REDD+ to recipient countries. Industrialized nations assumed the commitment under the UNFCCC regime to mobilize at least USD 100 billion per year by 2020 from a wide variety of sources for mitigation and adaptation actions in developing countries, according to their needs and national priorities (UNFCCC, 2015). REDD+ financing is specified in the Paris Agreement as it:

recognizes the importance of adequate and predictable financial resources, including for results-based payments, as appropriate, for the implementation of policy approaches and positive incentives for reducing emissions from deforestation and forest degradation, and the role of conservation, sustainable management of forests and enhancement of forest carbon stocks; as well as alternative policy approaches, such as joint mitigation and adaptation approaches for the integral and sustainable management of forests; while reaffirming the importance of non-carbon benefits associated with such approaches; encouraging the coordination of support from, inter alia, public and private, bilateral and multilateral sources, such as the Green Climate Fund, and alternative sources in accordance with relevant decisions by the Conference of the Parties. (UNFCCC, 2015, p. 8, para. 55)

The emerging REDD+ regime, which aims at preventing, mitigating and adapting to climate change, is embedded in larger governance architecture across different levels. Institutional arrangements in REDD+ occur at all levels, including the top-down Warsaw Framework for REDD+ (WFR), policies and measures at the national level, combined with bottom-up strategies for implementation, considering the participation of lower levels, such as implementing agencies, civil society entities, and other important stakeholders (Corbera \& Schroeder, 2011).

At the international level, several bilateral and multilateral agreements such as the UNREDD Programme, the World Bank's Forest Carbon Partnership Facility (FCPF), and the Forest Investment Program (FIP) have been supporting developing countries to implement REDD+. Major donor countries have been investing in REDD+ activities since 2008.

At the country level, Brazil is the largest and most advanced recipient country. It has received more than USD 1 billion from the governments of Norway and Germany through results-based payments channeled into the Amazon Fund (Amazon Fund, 2017, September 21), which is the largest REDD+ program in the world and the most important experiment due to the political importance of its international cooperation agreements with Norway and Germany (Boucher, Elias, Faires, \& Smith, 2014).

Furthermore, Brazil has set new standards for international cooperation in environmental protection and climate change by involving multiple stakeholders in the governance and implementation of REDD+ activities. It has demonstrated the feasibility of the results-based mechanism focused on mitigation by fulfilling donors' expectations of accountability and transparency of results in cooperation agreements and showing that it is possible to establish goals and metrics to reduce emissions from deforestation and forest degradation. Indeed, the Brazilian experiment has demonstrated to the international community that it is possible to give autonomy to a developing country to decide on how to manage REDD+ resources according to national priorities and ownership of the implementation agenda based on transparency and verified results before receiving results-based payments.

All told, the main purpose of our study it to present the state of the art review in REDD+ studies, justified by the relevance of the mechanism to mitigate climate change. This paper is organized as follow. Section two presents a systematic analysis of peer-reviewed articles on REDD+. Section three presents an historical perspective on REDD+. Section four presents a literature review based on the state of art articles identified in the systematic analysis, followed by the conclusion in the final section. 


\section{SYSTEMATIC ANALYSIS OF REDD+ STUDIES}

The literature focused on REDD+ is very recent and emergent, as per the contemporaneity of the mechanism. A systematic literature review of peer-reviewed articles conducted in November 2015 showed that the first work which indexed the word 'REDD' was published in 2007. From a sample of 863 articles found in the Web of Knowledge database, only three articles were published in 2007, 18 in 2008, and 25 in 2009.

The academic production focusing on REDD+ has consistently increased over the years, with a peak of 218 articles published in 2014. The majority of the works have a quantitative approach, including works on mapping forest carbon emissions and carbon stocks (Asner et al., 2010; Gibbs, Brown, Niles, \& Foley, 2007; Mitchard et al., 2014; Saatchi et al., 2011); forest biomass assessments (Danielsen et al., 2011; Henry et al., 2010; West, Vidal, \& Putz, 2014); and economic assessments of REDD+ (Bellassen \& Gitz, 2008; Busch et al., 2012; Venter et al., 2009).

Several qualitative studies are focused on the governance and implementation of REDD+ programs (Bolin, Mustalahti, Boyd, \& Paavola, 2012; Hajek, Ventresca, Scriven, \& Castro, 2011; Marcovitch \& Pinsky, 2014; Peskett, Schreckenberg, \& Brown, 2011). Others focus on the political dimensions of REDD+ in light of forest tenure and carbon rights (Larson et al., 2013; Lyster, 2011; Sandbrook, Nelson, Adam, \& Agrawal, 2010; Schroeder, 2010), social safeguards (McDermott, Coad, Helfgott, \& Schroeder, 2012), major drivers of deforestation (Hansen, Lund, \& Treue, 2009), and the implementation of MRV systems (Gupta, Lövbrand, Turnhout, \& Vijge, 2012; Herold \& Skutsch, 2011).

Previous studies provided important guidelines for the architecture of the emerging international REDD+ regime. Examples are the works of Corbera, Estrada, and Brown (2010), Corbera and Schroeder (2011), Gupta (2012), Hajek, Ventresca, Scriven, and Castro (2011), Kanowski, McDermott, and Cashore (2011), Karsenty (2008), Levin, McDermott, and Cashore (2008), Park, Choi, and Youn (2013), Phelps, Webb, and Agrawal (2010), and Somorin et al. (2012). Most of these studies have a political economics approach.

A more specific search was performed in June 2017 in the same Web of Knowledge database, using the key words 'REDD' combined with 'governance' and 'forest' for filtering purposes, resulting in 320 articles. The first article was published in 2007 , and the first citation was in 2008, as shown in Figure 1.

Figure 1: REDD+ Governance - Total Publications by Year

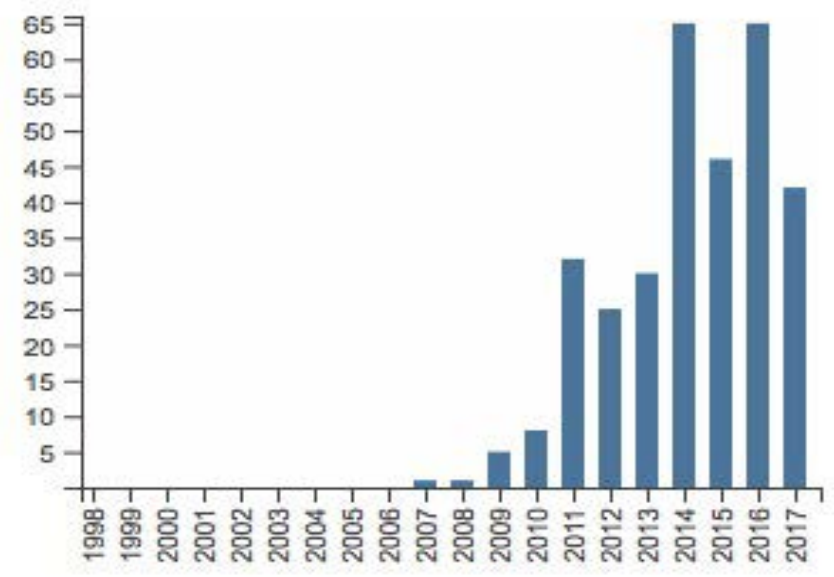

Source: Extracted from the Web of Knowledge database (2017, June 30). 
Despite the growing body of literature on REDD+ governance, academic production is incipient and concentrated on a small number of scholars. It is interesting to note that 24 scholars are responsible for $50 \%$ of the actual works on REDD+ governance (see Table 1).

Table 1: REDD+ Governance - Production by Author

\begin{tabular}{cccccccc}
\hline$\#$ & Authors & Records & \% of 320 & $\#$ & Authors & Records & \% of 320 \\
\hline 1 & Brockhaus, M. & 21 & 6.6 & 13 & Sonwa, D. & 5 & 1.6 \\
\hline 2 & Di Gregorio, M. & 14 & 4.4 & 14 & Somorin, O. & 5 & 1.6 \\
\hline 3 & Visseren-Hamakers, I. & 11 & 3.4 & 15 & Pham, T. & 5 & 1.6 \\
\hline 4 & Van Noordwijk, M. & 8 & 2.5 & 16 & Moeliono, M. & 5 & 1.6 \\
\hline 5 & Arts, B. & 7 & 2.2 & 17 & Mertz, O. & 5 & 1.6 \\
\hline 6 & Mustalahti, I. & 6 & 1.9 & 18 & Mcdermott, C. & 5 & 1.6 \\
\hline 7 & Larson, A. & 6 & 1.9 & 19 & Lund, J. & 5 & 1.6 \\
\hline 8 & Krause, T. & 6 & 1.9 & 20 & Giessen, L. & 5 & 1.6 \\
\hline 9 & Herold, M. & 6 & 1.9 & 21 & Gebara, M. & 5 & 1.6 \\
\hline 10 & Duchelle, A. & 6 & 1.9 & 22 & Gallemore, C. & 5 & 1.6 \\
\hline 11 & Corbera, E. & 6 & 1.9 & 23 & Vijge, M. & 4 & 1.25 \\
\hline 12 & Tacconi L & 5 & 1.6 & 24 & Vedeld Po & 4 & 1.25 \\
\hline
\end{tabular}

Source: Adapted by the author from the Web of Knowledge database (2017, June 30).

These 320 papers have been cited 3,759 times from 1,942 citing articles. The most cited articles are listed in Table 2.

Table 2: REDD+ Governance - Most Cited Articles

\begin{tabular}{|c|c|c|c|}
\hline Authors & Article & Journal & Cited \\
\hline $\begin{array}{l}\text { Phelps, Webb, \& Agrawal } \\
\text { (2010) }\end{array}$ & $\begin{array}{c}\text { Does REDD + Threaten to Recentralize For- } \\
\text { est Governance? }\end{array}$ & Science & 212 \\
\hline Corbera \& Schroeder (2011) & Governing and implementing REDD+ & $\begin{array}{l}\text { Environmental Science } \\
\text { and Policy }\end{array}$ & 144 \\
\hline $\begin{array}{c}\text { Börner, Wunder, Wertz-Ka- } \\
\text { nounnikoff, Tito, Pereira, \& } \\
\text { Nascimento (2010) }\end{array}$ & $\begin{array}{l}\text { Direct conservation payments in the Brazil- } \\
\text { ian Amazon: Scope and equity implications }\end{array}$ & Ecological Economics & 99 \\
\hline Larson (2011) & $\begin{array}{l}\text { Forest tenure reform in the age of climate } \\
\text { change: Lessons for REDD+ }\end{array}$ & $\begin{array}{l}\text { Global Environmental } \\
\text { Change }\end{array}$ & 83 \\
\hline $\begin{array}{l}\text { Beymer-Farris \& Bassett } \\
\text { (2012) }\end{array}$ & $\begin{array}{l}\text { The REDD menace: Resurgent protectionism } \\
\text { in Tanzania's mangrove forests }\end{array}$ & $\begin{array}{l}\text { Global Environmental } \\
\text { Change }\end{array}$ & 82 \\
\hline
\end{tabular}

Source: Adapted by the author from Web of Knowledge database (2017, June 30).

The search was refined to articles by researchers from Brazil, resulting in only 19 articles. It is interesting to note that most of these articles have a large number of co-authors, except for the works of Gebara and Agrawal (2017), Roessing Neto (2015), and Cronkleton, Bray, and Medina (2011). This leads us to the conclusion that studies in the REDD+ governance field involving Brazilian scholars have been conducted by research groups. Maria Fernanda Gerbara is the Brazilian researcher that has the highest number of publications, with $26.3 \%$ of 19 articles. 


\section{HISTORICAL PERSPECTIVE ON REDD+}

Reducing Emissions from Deforestation and Forest Degradation (REDD+) is a results-based mechanism in which developing countries receive incentives to improve forest management by attributing an economic value to the additional carbon stored in trees or not emitted. Since 2007, UNFCCC has provided guidance on REDD+ as a policy instrument to curb emissions from land use changes in developing countries (Corbera \& Schroeder, 2011).

The initial discussion on the need to develop a incentive mechanism focused on mitigation of forest-related carbon took place during the Kyoto Protocol negotiations in 1997 (Holloway \& Giandomenico, 2009). In 1998, the UNFCCC requested from the Intergovernmental Panel on Climate Change (IPCC) a report examining the scientific and technical implications of carbon sequestration strategies related to land use, land-use change, and forestry activities. This report consolidated important information on the scientific and technical aspects of carbon sequestration in agricultural and forestry sectors, as well as its implications for resource management, and socioeconomic development issues (IPCC, 2000).

The first commitment period of the Kyoto Protocol allowed industrialized countries to achieve their reduction target by acquiring offsets from projects eligible for certified emission reductions, through three different market-based mechanisms: CDM, international emissions trading, and joint implementation. Article 12 of the Kyoto Protocol states that only afforestation and reforestation projects could generate credits for trading under the CDM mechanism (UNFCCC, 2006).

However, the Marrakesh Accord, negotiated at the COP-7, only considered afforestation and reforestation activities, and reductions of emissions from tropical deforestation were not be eligible for carbon credits (UNFCCC, 2001). In 2003, a group of Brazilian and American scholars first suggested the concept of 'compensated reduction' (Santilli et al., 2005) as a large-scale incentive to reduce emissions from tropical deforestation by compensating developing countries committed to reducing deforestation to below previously historical levels and to stabilize the reduced deforestation rate. The mechanism would also facilitate the participation of important developing counties in the Kyoto Protocol. The proposal was presented at the COP-9 in Milan in 2003.

Following this, a similar proposal, 'Reducing emissions from deforestation in developing countries: approaches to stimulate action', was formally presented at the COP-11, held in Montreal in 2005, by the governments of Papua New Guinea and Costa Rica, on behalf of the Coalition of Rainforest Nations. The coalition recommended two proposals to address emissions from deforestation: 1) an optional protocol under the UNFCCC, or 2) a set of decisions under the Kyoto Protocol to allow emissions from tropical deforestation to be considered in market-based schemes (UNFCCC, 2005).

REDD became a formal global mechanism only in 2007 at the COP-13. The Bali Action Plan (Decision 1/CP.13) established an international call for action on the mitigation of climate change, including "policy approaches and positive incentives on issues relating to reducing emissions from deforestation and forest degradation in developing countries; and the role of conservation, sustainable management of forests and enhancement of forest carbon stocks in developing countries" (UNFCCC, 2008, p. 3). This REDD concept was called REDD plus (REDD+) due to the additional inclusion of the sustainable management of forests, the role of conservation, and the enhancement of forest carbon stocks.

Since COP-13, key important decisions on REDD+ have been made, including a road map to insert the mechanism into a future global climate agreement (Seymour \& Forwand, 2010). The Copenhagen Accord, established at the COP-15 in 2009, expressed strong support for REDD+ as a financial mechanism to mobilize financial resources from developed countries. 
It was decided that "the Copenhagen Green Climate Fund shall be established as an operating entity of the financial mechanism of the Convention to support projects, programs, policies and other activities in developing countries related to mitigation including REDD+, adaptation, capacity-building, technology development and transfer" (UNFCCC, 2010, p. 7).

The WFR, adopted by UNFCCC Parties at the COP-19 in 2013, designed a robust and comprehensive framework for REDD+ implementation, including guidance on measurement, reporting and verification (MRV) to certify emission reduction as a critical element to access results-based payments through tangible results (UNFCCC, 2014; Voigt \& Ferreira, 2015).

The REDD+ architecture, approved by Parties at the COP-16 in Cancun, requires recipient countries to implement four elements in order to access results-based payments from donor countries: 1) national strategy or action plan; 2) national forestry monitoring system, including MRV; 3 ) forest reference emission levels (FREL) and/or forest reference level, and 4) safeguards information system (UNFCCC, 2011). Furthermore, UNFCCC recommends a phased approach to implement these elements through a flexible and interactive approach, because of the complexity involved in the process that depends on developing countries' circumstances and capacities (Voigt \& Ferreira, 2015).

\section{GOVERNING AND IMPLEMENTING REDD+}

As governance drives policy effectiveness (World Bank, 2017, p. 43), governance-related processes on REDD+ require coordination between public policies at national, subnational, and local levels aiming at effectiveness in emission reduction from deforestation and forest degradation, quantified and integrated at a national level (Gomes et al., 2010). Thompson, Baruah, and Carr (2011) point out that REDD+ is more than a mitigation mechanism. In fact, "REDD+ is already functioning as a form of governance, a particular framing of the problem of climate change and its solutions that validates and legitimizes specific tools, actors and solutions while marginalizing others" (p. 100).

The REDD+ governance architecture is based on a national level coordination led by governments, with subnational activities implemented in cooperation with government agencies (Corbera \& Schroeder, 2011). Although governments have increased the decentralization of forest policies and management to reduce costs and increase efficiency, the implementation of REDD+ may reverse this trend due to requirements under the UNFCCC regime to have a centralized REDD+ at the national level, including a national strategy, and a centralized MRV system (Agrawal, Chhatre, \& Hardin, 2008; Phelps, Webb, \& Agrawal, 2010). While the national level centralizes the REDD+ policy-making process and governance, subnational governments and lower-level agents are responsible for policy implementation (Luttrell, Sills, Aryani, Ekaputri, \& Evnike, 2016).

According to the WFR, results-based mechanism for REDD+ embraces a centralized national level approach by linking MRV processes to reporting obligations of developing countries under the UNFCCC. A national entity or national focal point for REDD+ should be responsible for coordination, safeguards and MRV, while subnational agencies or institutions are responsible for implementing activities. This has increased the transparency of the implementation process, aiming to access results-based finance as the national government assumes accountability for the results. The centralized approach also avoids the double counting of REDD+ results (Voigt \& Ferreira, 2015).

In a state-centric REDD+ approach, national governments are accountable for establishing national strategies and policies for land use and forest sectors, including land and carbon tenure, MRV system, provision of funds, and safeguards. Actors at the subnational level (private landholders, local governments, and communities) may be responsible for implementing activities and receive incentives to reduce emissions (Phelps et al., 2010). 
At the international level, it is argued that REDD+ is the most important carbon governance mechanism to address the global warming problem as deforestation is a major driver of climate change, and REDD+ is considered an effective mitigation approach (Lederer, 2012). Others stress that an integrated approach involving international, national and subnational governance levels is required for REDD+ to progress (Korhonen-Kurki, Brockhaus, Duchelle, Atmadja, \& Thuy, 2012). Some go further and believe that the implementation of REDD+ should be consistent with principles of good forest governance (Kanowski et al., 2011).

At the national level, Korhonen-Kurki et al. (2012) contribute to the discussion on the challenges and opportunities of multilevel governance. Risks of conflict between actors can be reduced with a REDD+ multilevel governance system since it matches incentives and interests in a transparent way. This is corroborated by Corbera et al. (2010), who argue that "governance of land use change is a multi-sectorial issue, which requires coordination and institutional adaptation by all the agents involved" (p. 379).

Forsyth (2009) also points out the benefits of a multilevel participatory governance structure in REDD+ to build new political processes based on participation, consensus building and collective learning. Despite the divergent views and interests of stakeholders, if the processes are collectively deliberated, chances for long-term efficiency and effectiveness of REDD+ results are more likely to happen by overcoming divergent interests between actors and institutions.

According to Corbera and Schroeder (2011), national strategies for REDD+, including policies and measures, depend on a country's circumstances, taking into account its economic, political, historical and environmental contexts. Korhonen-Kurki et al. (2012) list some of the REDD+ elements that require a multilevel governance for implementation, including monitoring, measuring and reporting, forest reference levels, leakage, permanence, benefit sharing and financial mechanisms, participation and rights of indigenous people and traditional communities, non-carbon benefits, and land tenure. All these elements have multilevel governance challenges related to the integration of actions at different levels.

According to Vatn and Angelsen (2009), the national governance structure for REDD+ defines the capabilities and responsibilities of actors, the rules and procedures for interactions, and distribution of power. Indeed, effective REDD+ implementation requires synergy between government at all levels and the communities involved, based on an institutional long-term strategy. Some other point out that payment for environmental service schemes, such as REDD+, cannot substitute command and control measures because its effectiveness depend on the latter to secure rights of exclusion (Börner, et al., 2010).

A full and effective participation of key stakeholders in REDD+ governance and implementation processes is required by UNFCCC, in particular indigenous peoples and local communities (UNFCCC, 2011). National governments are responsible not only for trying to make different lower-level units work together during REDD+ implementation (Phelps et al., 2010) but also have to negotiate with important stakeholders so they can fulfill their forest subsistence needs (Doherty \& Schroeder, 2011).

Cronkleton, Bray, and Medina (2011) highlight the importance of establishing community forest management systems at the local level as a critical component in REDD+ governance at multiple levels. This is corroborated by Roessing Neto (2015), who argues that the involvement of local actors through the establishment of local governance arrangements is a key for the implementation of REDD+ activities, in consonance with national policy instruments.

Some argue that an effective involvement of key actors such as local communities and indigenous communities, willing to cooperate within REDD+ implementation, is critical in order to reach the aims of REDD+. On the other hand, the lack of coordination between state and nonstate actors is a constraint for the governance and implementation of a national strategy for REDD+ (Gebara, Fatorelli, May, \& Zhang, 2014). 


\section{CONCLUSIONS}

REDD+ is a key mitigation strategy (Phelps, Webb, \& Agrawal, 2010) and an important policy instrument to reduce emissions from land use changes (Corbera \& Schroeder, 2011) in which transactions are based on already achieved mitigation results. REDD+ is an opportunity for transformational changes that, combined with structuring policies, instruments and incentives, may improve sustainable development in forest areas in developing counties. Understanding the REDD+ governance process is a critical field of study as the alteration of a nation's internal land use policies is one of the greatest challenges in climate change, and if successful, this could have a very large impact on GHG emissions. Governing and implementing REDD+ is an high complex process because the drivers of deforestation are multi level and require policy coordination across sectors through different institutional arrangements.

This study presents a systematic review of academic articles on REDD+, and identifies the state of art in the field by pointing out the most relevant articles and scholars in the field. Furthermore, we present a historical context on the emergence of REDD+ at the international level, and a literature review on governing and implementing REDD+, which can be used as a solid base in future researches related to REDD+ and forest governance.

\section{ACKNOWLEDGEMENTS}

This work was supported by the São Paulo Research Foundation (FAPESP) processes 2014/11950-2 and 2014/21877-0.

\section{REFERENCES}

Ab'Sáber, A., Goldemberg, J., Rodés, L., \& Zulauf, W. (1990). Identificação de áreas para o florestamento no espaço total do Brasil. Estudos Avançados, 4(9), 63-119. http://doi.org/10.1590/ S0103-40141990000200005

Agrawal, A., Chhatre, A., \& Hardin, R. (2008). Changing Governance of the World's Forests. Science, 320(1460), 1460-1462. doi:10.1126/science.1155369

Amazon Fund. (2017, September 21). Donations. Available at http://www.amazonfund.gov.br/ FundoAmazonia/fam/site_en/Esquerdo/doacoes/

Angelsen, A. and MacNeill, D. (2012). The Evolution of REDD+. In: A. Angelsen, M. Brockhaus, W. D. Sunderlin and L. V. Verchot (Eds.), Analysing REDD+: Challenges and Choices (pp. 31-49). CIFOR, Bogor, Indonesia.

Asner, G. P., Powell, G. V. N., Mascaro, J., Knapp, D. E., Clark, J. K., Jacobson, J., ... Hughes, R. F. (2010). High-resolution forest carbon stocks and emissions in the Amazon. Proceedings of the National Academy of Sciences, 107(38), 16738-16742. doi:10.1073/pnas.1004875107

Bellassen, V., \& Gitz, V. (2008). Reducing emissions from deforestation and degradation in Cameroon-assessing costs and benefits. Ecological Economics, 68(1), 336-344.

Beymer-Farris, B. a., \& Bassett, T. J. (2012). The REDD menace: Resurgent protectionism in Tanzania's mangrove forests. Global Environmental Change, 22(2), 332-341. http://doi. org/10.1016/j.gloenvcha.2011.11.006 
Bolin, A., Mustalahti, I., Boyd, E., \& Paavola, J. (2012). Can REDD+ reconcile local priorities and needs with global mitigation benefits? Lessons from Angai Forest, Tanzania. Ecology and Society, 17(1).

Börner, J., Wunder, S., Wertz-Kanounnikoff, S., Tito, M. R., Pereira, L., \& Nascimento, N. (2010). Direct conservation payments in the Brazilian Amazon: Scope and equity implications. Ecological Economics, 69(6), 1272-1282. http://doi.org/10.1016/j.ecolecon.2009.11.003

Boucher, D., Elias, P., Faires, J., \& Smith, S. (2014). Deforestation success stories: Tropical nations where forest protection and reforestation policies have worked. Tropical Forest and Climate Initiative. Retrieved from http://www.ucsusa.org/sites/default/files/legacy/assets/documents/ global_warming/deforestation-success-stories-2014.pdf

Busch, J., Lubowski, R. N., Godoy, F., Steininger, M., Yusuf, A. A., Austin, K., ... \& Boltz, F. (2012). Structuring economic incentives to reduce emissions from deforestation within Indonesia. Proceedings of the National Academy of Sciences, 109(4), 1062-1067.

Corbera, E., \& Schroeder, H. (2011). Governing and implementing REDD+. Environmental Science and Policy, 14(2), 89-99. http://doi.org/10.1016/j.envsci.2010.11.002

Corbera, E., Estrada, M., \& Brown, K. (2010). Reducing greenhouse gas emissions from deforestation and forest degradation in developing countries: revisiting the assumptions. Climatic Change, 100(3-4), 355-388. http://doi.org/10.1007/s10584-009-9773-1

Cronkleton, P., Bray, D. B., \& Medina, G. (2011). Community forest management and the emergence of multi-scale governance institutions: Lessons for REDD+ development from Mexico, Brazil and Bolivia. Forests, 2(2), 451-473. http://doi.org/10.3390/f2020451

Cruz, T. S., Gomes, S. M. S., Oliveira, N. C., \& Oliveira, N. S. (2017). Estratégias de enfrentamento às mudanças climáticas: um estudo com as empresas listadas no Índice de Sustentabilidade Empresarial da B3. Revista de Administração da Universidade Federal de Santa Maria, 10, 149-166.

Danielsen, F., Skutsch, M., Burgess, N. D., Jensen, P. M., Andrianandrasana, H., Karky, B., ... \& Zahabu, E. (2011). At the heart of REDD+: a role for local people in monitoring forests?. Conservation Letters, 4(2), 158-167.

Danigelis, A. (2018, December 12). COP24 Represents a Line in the Sand for Companies. Environmental Leader. Available at https://www.environmentalleader.com/2018/12/cop24companies/

De Farias, L. D. G. Q., \& Andrade, J. C. S. (2013). Respostas anunciadas pelas empresas brasileiras participantes do Carbon Disclosure Project para economia de baixo carbono. Revista de Administração da UFSM, 6(1), 157-172.

Doherty, E., \& Schroeder, H. (2011). Forest Tenure and Multi-level Governance in Avoiding Deforestation under REDD+. Global Environmental Politics, 11(4), 66-88. http://doi.org/10.1162/ GLEP_a_00084

Falkner, R., Stephan, H., \& Vogler, J. (2010). International Climate Policy after Copenhagen: Towards a "Building Blocks" Approach. Global Policy, 1(3), 252-262. doi:10.1111/j.17585899.2010.00045.x 
FAO. (2016). Global Forest Resources Assessment 2015. FAO Forestry. Rome. Retrieved from http://www.fao.org/forest-resources-assessment/current-assessment/en/

Forsyth, T. (2009). Multilevel, multiactor governance in REDD+: Participation, integration and coordination. In: Angelsen, A. (2009). Realising REDD+: National strategy and policy options. (A. Angelsen, M. Brockhaus, E. Kanninen, M., Sills, W. D. Sunderlin, \& S. Wertz-Kanounnikoff, Eds.). Bogor, Indonesia: CIFOR. http://doi.org/361

Gebara, M. F., \& Agrawal, A. (2017). Beyond Rewards and Punishments in the Brazilian Amazon: Practical Implications of the REDD+ Discourse. Forests, 8(3), 66.

Gebara, M. F., Fatorelli, L., May, P., \& Zhang, S. (2014). REDD+ policy networks in Brazil: Constraints and opportunities for successful policy making. Ecology and Society, 19(3). http:// doi.org/10.5751/ES-06744-190353

Gibaut, E. A., \& Dias Filho, J. M. (2016). As respostas das empresas brasileiras às mudanças climáticas: uma análise à luz da teoria da legitimidade. Revista de Administração da Universidade Federal de Santa Maria, (9).

Gibbs, H. K., Brown, S., Niles, J. O., \& Foley, J. a. (2007). Monitoring and estimating tropical forest carbon stocks: making REDD a reality. Environmental Research Letters, 2(4), 045023. doi:10.1088/1748-9326/2/4/045023

Gomes, R., Bone, S., Cunha, M., Nahur, A. C., Moreira, P. F., Meneses-Filho, L. C., ... \& Moutinho, P. (2010). Exploring the bottom-up generation of REDD+ policy by forest-dependent peoples. Policy Matters, 17, 161-168.

Gupta, A., Lövbrand, E., Turnhout, E., \& Vijge, M. J. (2012). In pursuit of carbon accountability: the politics of REDD+ measuring, reporting and verification systems. Current Opinion in Environmental Sustainability, 4(6), 726-731.

Gupta, J. (2012). Global forest and REDD+ governance: win-win or lose-lose?. Current Opinion in Environmental Sustainability, 4(6), 620-627.

Hajek, F., Ventresca, M. J., Scriven, J., \& Castro, A. (2011). Regime-building for REDD+: Evidence from a cluster of local initiatives in south-eastern Peru. Environmental Science \& Policy, 14(2), 201-215.

Hansen, C. P., Lund, J. F., \& Treue, T. (2009). Neither Fast, Nor Easy: He Prospect of Reduced Emissions from Deforestation and Degradation (REDD) in Ghana. International Forestry Review, 11(4), 439-455.

Henry, M., Besnard, A., Asante, W. A., Eshun, J., Adu-Bredu, S., Valentini, R., ... \& Saint-André, L. (2010). Wood density, phytomass variations within and among trees, and allometric equations in a tropical rainforest of Africa. Forest Ecology and Management, 260(8), 1375-1388.

Herold, M., \& Skutsch, M. (2011). Monitoring, reporting and verification for national REDD+ programmes: two proposals. Environmental Research Letters, 6(1), 014002.

Holloway, V., \& Giandomenico, E. (2009). The History of REDD Policy. History. Adelaide, SA. Retrieved from www.carbonplanet.com 
IPCC. (2000). Land use, land-use change, and forestry. IPCC Special Report - Summary for Policy Makers. Retrieved from https://www.ipcc.ch/pdf/special-reports/spm/srl-en.pdf

Kaisa, K. K., Maria, B., Efrian, M., Sirkku, J., Moira, M., Cynthia, M., \& Bimo, D. (2017). Analyzing REDD+ as an experiment of transformative climate governance: Insights from Indonesia. Environmental Science and Policy, 73, 61-70. http://doi.org/10.1016/j.envsci.2017.03.014

Kanowski, P. J., McDermott, C. L., \& Cashore, B. W. (2011). Implementing REDD+: lessons from analysis of forest governance. Environmental Science \& Policy, 14(2), 111-117. http://doi. org/10.1016/j.envsci.2010.11.007

Karsenty, A. (2008). The architecture of proposed REDD schemes after Bali: facing critical choices. International Forestry Review, 10(3), 443-457. doi:10.1505/ifor.10.3.443

Korhonen-Kurki, K., Brockhaus, M., Duchelle, A. E., Atmadja, S., \& Thuy, P. T. (2012). Multiple levels and multiple challenges for REDD+. In: Angelsen, A., Brockhaus, M., Sunderlin, W. D., \& Verchot, L. V. Eds. (2012). Analysing REDD+ Challenges and Choices. Bangor, Indonesia: CIFOR. http://doi.org/10.17528/cifor/003805

Krug, T. (2008). Impacto, vulnerabilidade e adaptação das florestas à mudança do clima. Parcerias Estratégicas, (27), 43-72. Retrieved from http://seer.cgee.org.br/index.php/parcerias_ estrategicas/article/viewFile/332/326

Larson, A. M. (2011). Forest tenure reform in the age of climate change: Lessons for REDD+. Global Environmental Change, 21(2), 540-549. http://doi.org/10.1016/j.gloenvcha.2010.11.008

Larson, A. M., Brockhaus, M., Sunderlin, W. D., Duchelle, A., Babon, A., Dokken, T., ... \& Huynh, T. B. (2013). Land tenure and REDD+: the good, the bad and the ugly. Global Environmental Change, 23(3), 678-689.

Lederer, M. (2012). REDD+ governance. Wiley Interdisciplinary Reviews: Climate Change, 3(1), 107-113. http://doi.org/10.1002/wcc.155

Levin, K., McDermott, C., \& Cashore, B. (2008). The climate regime as global forest governance: can reduced emissions from Deforestation and Forest Degradation (REDD) initiatives pass a "dual effectiveness" test? International Forestry Review, 10(3), 538-549. doi:10.1505/ifor.10.3.538

Luttrell, C., Sills, E. O., Aryani, R., Ekaputri, A. D., \& Evnike, M. F. (2016). Who will bear the cost of $R E D D+$ ? Evidence from subnational REDD+ initiatives (No. 204). Bangor, Indonesia.

Lyster, R. (2011). REDD+, transparency, participation and resource rights: the role of law. Environmental science \& policy, 14(2), 118-126.

Marcovitch, J., \& Pinsky, V. C. (2014). Amazon Fund: financing deforestation avoidance. Revista de Administração, 49, 280-290. doi:10.5700/rausp1146

McDermott, C. L., Coad, L., Helfgott, A., \& Schroeder, H. (2012). Operationalizing social safeguards in REDD+: Actors, interests and ideas. Environmental Science and Policy, 21, 63-72. doi:10.1016/j. envsci.2012.02.007

Mitchard, E. T., Feldpausch, T. R., Brienen, R. J., Lopez-Gonzalez, G., Monteagudo, A., Baker, T. R., ... \& Pardo Molina, G. (2014). Markedly divergent estimates of Amazon forest carbon density from ground plots and satellites. Global ecology and biogeography, 23(8), 935-946.

Rev. AdM. UFSM, SANTA MARIA, v. 12, NúMERo 1, P. 182-197, 2019 
Park, M. S., Choi, E. S., \& Youn, Y. C. (2013). REDD+ as an international cooperation strategy under the global climate change regime. Forest Science and Technology, 9(4), 213-224. doi:10.1080/21 580103.2013.846875

Peskett, L., Schreckenberg, K., \& Brown, J. (2011). Institutional approaches for carbon financing in the forest sector: Learning lessons for REDD+ from forest carbon projects in Uganda. Environmental Science and Policy, 14(2), 216-229. http://doi.org/10.1016/j.envsci.2010.10.004

Phelps, J., Guerrero, M. C., Dalabajan, D. a., Young, B., \& Webb, E. L. (2010). What makes a "REDD" country? Global Environmental Change, 20(2), 322-332. http://doi.org/10.1016/j. gloenvcha.2010.01.002

Phelps, J., Webb, E. L., \& Agrawal, A. (2010). Does REDD + Threaten to Recentralize Forest Governance? Science, 328(April), 312-313.

Prins, G., \& Rayner, S. (2007). The Wrong Trousers: Radically Rethinking Climate Policy. James Martin Institute for Science and Civilization, University of Oxford and the MacKinder Centre for the Study of Long-Wave Events, London School of Economics. Retrieved from http://eureka.bodleian. ox.ac.uk/66/1/TheWrongTrousers.pdf

Roessing Neto, E. (2015). REDD+ as a tool of global forest governance. The International Spectator: Italian Journal of International Affairs, 50(March), 60-73. http://doi.org/10.1080/03932729.201 5.983700

Saatchi, S. S., Harris, N. L., Brown, S., Lefsky, M., Mitchard, E. T. A., Salas, W., ... Morel, A. (2011). Benchmark map of forest carbon stocks in tropical regions across three continents. Proceedings of the National Academy of Sciences, 108(24), 9899-9904. doi:10.1073/pnas.1019576108

Sandbrook, C., Nelson, F., Adams, W. M., \& Agrawal, A. (2010). Carbon, forests and the REDD paradox. Oryx, 44(03), 330-334.

Santilli, M., Moutinho, P., Schwartzman, S., Nepstad, D., Curran, L., \& Nobre, C. (2005). Tropical deforestation and the Kyoto Protocol. Climatic Change, 71(3), 267-276.

Schroeder, H. (2010). Agency in international climate negotiations: the case of indigenous peoples and avoided deforestation. International Environmental Agreements: Politics, Law and Economics, 10(4), 317-332. doi:10.1007/s10784-010-9138-2

Seymour, F., \& Forwand, E. (2010). Governing sustainable forest management in the new climate regime. Wiley Interdisciplinary Reviews: Climate Change, 1(6), 803-810.

Smith, P., Bustamante, M., Ahammad, H., Clark, H., Dong, H., Elsiddig, E. A., ... Tubiello, F. (2014). Agriculture, Forestry and Other Land Use (AFOLU). In Climate Change 2014: Mitigation of climate change. Contribution of Working Group III to the Fifth Assessment Report of the Intergovernmental Panel on Climate Change. O. Edenhofer, R. Pichs-Madruga, Y. Sokona, E. Farahani, S. Kadner, K. Seyboth, ... J. C. Minx (Eds.) (pp. 812-922). Cambridge, UK and New York, USA: Cambridge University Press. http://doi.org/10.1017/СBO9781107415416

Somorin, O. A., Brown, H. C. P., Visseren-Hamakers, I. J., Sonwa, D. J., Arts, B., \& Nkem, J. (2012). The Congo Basin forests in a changing climate: policy discourses on adaptation and mitigation (REDD+). Global Environmental Change, 22(1), 288-298. 
Stern. (2007). Stern Review on the Economics of Climate Change. Journal of Economic Literature, 7(4), 233-724. doi:10.1257/jel.45.3.703

Thompson, M. C., Baruah, M., \& Carr, E. R. (2011). Seeing REDD+ as a project of environmental governance. Environmental Science and Policy, 14(2), 100-110. http://doi.org/10.1016/j. envsci.2010.11.006

UNFCCC. (2001). The Marrakesh Accords \& The Marrakesh Declaration. doi:10.1016/S14710846(02)80006-3

UNFCCC. (2005). Reducing emissions from deforestation in developing countries: approaches to stimulate action. Item 6 of the provisional agenda. Retrieved from http://unfccc.int/resource/ docs/2005/cop11/eng/misc01.pdf

UNFCCC. (2006). Report of the Conference of the Parties serving as the meeting of the Parties to the Kyoto Protocol on its first session, held at Montreal from 28 November to 10 December 2005. Part Two: Action taken by the Conference of the Parties serving as the meeting of the Parties to the Kyoto Protocol on its first session. Retrieved from http://unfccc.int/resource/docs/2005/ cmp1/eng/08a01.pdf\#page $=6$

UNFCCC. (2008). Report of the Conference of the Parties on its thirteenth session, held in Bali from 3 to 15 December 2007. FCCC/CP/2007/6/Add.1. doi:10.1016/j.biocon.2006.08.013

UNFCCC. (2010). Report of the Conference of the Parties on its fifteenth session, held in Copenhagen from 7 to 19 December 2009. Decision 1/CP.15. Retrieved from http://unfccc.int/ resource/docs/2009/cop15/eng/11a01.pdf

UNFCCC. (2014). Decision booklet REDD+. Key decisions relevant for reducing emissions from deforestation and forest degradation in developing countries (REDD+). Retrieved from http:// unfccc.int/6917.php

UNFCCC. (2015). Adoption of the Paris Agreement. Paris. Retrieved from http://unfccc.int/ resource/docs/2015/cop21/eng/l09r01.pdf. Accessed: 2/26/2017.

Van der Werf, G.R., Morton, D.C., DeFries, R.S., Olivier, J.G.J., Kasibhatla, P.S., Jackson, R.B., Collatz, G.J., Randerson, J.T., 2009. CO2 emissions from forest loss. Nat. Geosci. 2, 737-738

Vatn, A., \& Angelsen, A. (2009). Options for a national REDD+ architecture. In: Angelsen, A. (2009). Realising REDD+: National strategy and policy options. (A. Angelsen, M. Brockhaus, E. Kanninen, M., Sills, W. D. Sunderlin, \& S. Wertz-Kanounnikoff, Eds.). Bogor, Indonesia: CIFOR. http://doi.org/361

Venter, O., Meijaard, E., Possingham, H., Dennis, R., Sheil, D., Wich, S., ... \& Wilson, K. (2009). Carbon payments as a safeguard for threatened tropical mammals. Conservation letters, 2(3), 123-129.

Victor, D. G. (2011). Global warming gridlock: creating more effective strategies for protecting the planet. Cambridge University Press.

Voigt, C., \& Ferreira, F. (2015). The Warsaw Framework for REDD+: Implications for National Implementation and Access to Results-based Finance. Carbon \& Climate Law Review: CCLR, 9 (2), 113-129. 
West, T. A., Vidal, E., \& Putz, F. E. (2014). Forest biomass recovery after conventional and reducedimpact logging in Amazonian Brazil. Forest Ecology and Management, 314, 59-63.

World Bank. (2017). World Development Report 2017: Governance and the Law. Washington, DC. Retrieved from http://www.worldbank.org/en/publication/wdr2017 